\title{
Perancangan Sistem Penyewaan Bus Berbasis Laravel Framework PT Sumber Jaya Trans Tangerang
}

\author{
Dzakwan Taqiyyuddin Al Fatah*1, Sari Safitri ${ }^{2}$, Wahyu Manurian ${ }^{3}$ \\ ${ }^{1}$ Program Studi Teknik Informatika Fakultas Sains dan Teknologi Universitas Raharja, \\ ${ }^{2}$ Program Studi Sistem Informasi Fakultas Sains dan Teknologi Universitas Raharja, ${ }^{3}$ Program \\ Studi Manajemen Informatika Fakultas Sains dan Teknologi Universitas Raharja \\ E-mail: * ${ }^{1}$ dzakwan@ raharja.info, ${ }^{2}$ sari.safitri@ raharja.info, ${ }^{3}$ manurian@ raharja.info
}

\begin{abstract}
Abstrak
Kebutuhan alat transportasi khususnya di Kabupaten Tangerang, yang digunakan untuk liburan, wisata, studi tour merupakan peluang usaha yang menjanjikan bagi perusahaan transportasi. Karena kebutuhan alat transportasi tersebut penting untuk kelancaran kegiatannya. Perusahaan PT. Sumber Jaya Trans Tangerang yang terlibat dalam layanan pengangkutan penumpang, termasuk salah satu perusahaan yang bergerak di bidang ini. Dalam operasionalnya masih menggunakan sistem manual dalam penyewaan busnya. Banyak kendala yang terjadi dalam penyewaan bus ini, seperti proses bisnis yang belum terkomputerisasi, dan penyimpanan datanya yang kurang efektif dan efisien. Metode penelitian dalam analisis sistem yang digunakan adalah PIECES yaitu Performance, Information, Economy, Control, Efficiency dan Service. Perancangan sistem menggunakan metode analisa berorientasi objek dengan Unified Modeling Language (UML), bahasa pemrograman yang digunakan adalah PHP serta database yang digunakan adalah MySQL. Sistem ini berbasis web dan menggunakan bahasa pemrograman PHP 7, Perancangan Web dengan CSS Bootstrap, Laravel Framework dan MySQL untuk perancangan database, sedangkan software pendukung yang digunakan dalam pembuatan program adalah Visual Studio Code. Pada penelitian ini telah dibuat suatu sistem yang memiliki fitur seperti data master, transaksi, jadwal bus, tujuan, laporan transaksi, laporan surat perintah jalan dan log aktivitas. Dengan adanya sistem penyewaan bus ini proses penyewaan bus yang berjalan akan lebih efektif dan efisien.
\end{abstract}

Kata Kunci-Sistem Penyewaan, Laravel, PHP, PIECES

\begin{abstract}
The need for transportation for the community, especially in Tangerang Regency, which is used for holidays, tours, study tours, or pilgrimage. is a promising business opportunity for transportation companies. Because the need for transportation is important for the smooth running of its activities. PT. Sumber Jaya Trans Tangerang, which is involved in passenger transportation services, is one of the companies engaged in this field. In its operation still uses a manual system in renting buses. Many obstacles occur in this bus rental, such as business processes that have not been computerized, and data storage that is less effective and efficient. The research method in the analysis of the system used is PIECES which consists of Performance, Information, Economy, Control, Efficiency and Service. The system design uses object-oriented analysis method with Unified modeling Language (UML), the programming language used is PHP and the database used is MySQL. This system is web-based and uses the PHP 7 programming language, Web Design with CSS Bootstrap, Laravel Framework and MySQL for database design, while supporting software used in making programs is Visual Studio Code. In this research, a system has features such as master data, transactions, bus schedules, destinations, calendars, transaction reports, road warrant reports and activity logs. With this bus rental system, the bus rental process that is running will be more effective and efficient.
\end{abstract}

Keywords—Rental System, Laravel, PHP, PIECES 


\section{PENDAHULUAN}

Dunia saat ini didominasi dengan teknologi komputer yang sedang berkembang dengan pesatnya. Kehadiran banyak komputer memberikan manfaat bagi manusia dalam realisasi pekerjaan yang baik dan rumit. Dengan pengembangan teknologi komputer komunitas, diminta untuk membuka informasi dan guru teknologi.

Ketika teknologi itu diselaraskan dengan aktivitas bisnis yang ada diperusahaan, sehingga mampu meningkatkan kinerja perusahaan, maka peluang untuk meraih kesuksesan akan mudah terwujud, dengan adanya faktor tersebut pula dapat membantu dalam persaingan antar perusahaan sehingga penggunaan sistem informasi sangat diperlukan oleh perusahaan, termasuk pada perusahaan PT Sumber Jaya Trans Tangerang. PT Sumber Jaya Trans Tangerangadalah perusahaan swasta yang bergerak dalam bidang penyewaan armada transportasi bus pariwisata yang dapat menjangkau para penyewa dari dalam kota maupun luar kota termasuk di Kota Tangerang dan Kabupaten Tangerang.

\subsection{Rumusan Masalah}

1. Bagaimana proses bisnis yang sedang berjalan untuk penyewaan bus pariwisata pada PT Sumber Jaya Trans Tangerang?

2. Bagaimana merancang suatu sistem pengolahan datapenyewaan bus pariwisata pada PT Sumber Jaya Trans Tangerang?

3. Bagaimana penerapan sistem penyewaan bus pada PT Sumber Jaya Trans Tangerang?

\subsection{Tinjauan Pustaka}

1. Selmi dkk[1] Penelitian ini membahas dalam proses pemesanan tiket bus wisata yang tidak harus mengantri atau datang ke agen pariwisata wisata turis.

2. Kholili Rachman[2] Penelitian ini bertujuan untuk membantu proses penyewaan bus yang terkomputerisasi dan memudahkan orang yang sewa bus online saat mengakses aplikasi web.

3. Pinaringan Ageng Ginanjar dkk[3] Masalah yang dihadapi adalah banyak permintaan untuk layanan penyewaan bus pariwisata di P.O Blue Star membuat banyak perantarayang dapat membahayakan calon pelanggan. Selain itu, proses pemesanan menggunakan telepon atau datang langsung ke kantor perusahaan menyebabkan lebih sedikit waktu bagi calon pelanggan.

4. Hadi Zakaria dkk[4] Penelitian ini bertujuan untuk membantu proses reservasi online dengan tepat dan akurat, dan juga dapat meningkatkan kinerja karyawan CV. Abiyyu Trans berjalan lebih baik.

5. Tulus Wahyuno[5] Penelitian ini membahas tentang pemesanan tiket secara online dan website milik PO. Handoyo untuk memfasilitasi akses ke informasi tentang perusahaan.

\section{METODE PENELITIAN}

\subsection{Pengumpulan Data}

\subsubsection{Observasi}

Pengumpulan datayang diadakan pengamatan langsung pada lokasi penelitian apabila sesuai dengan tujuan penelitian.

\subsubsection{Wawancara}


Memperoleh data secara berkomunikasi langsung daristakeholder bus pariwisata tersebut. Penulis langsung bertanya dengan Ade Maman Selaku pembimbing lapangan PT Sumber Jaya Trans Tangerang.

\subsubsection{Studi Pustaka}

Mengumpulkan data berhubungan dengan penelitian lewat buku dan literatur lainnya untuk dijadikan landasan teori.

\subsection{Metode Analisis Sistem}

Selanjutnya data yang telah diperoleh pada saat melakukan observasi dan wawancara dikumpulkan serta dianalisis menggunakan metode analisa PIECES (Performance, Information, Economic, Control, Efficiency, Service). Dimana dalam menggunakannya, permasalahan dapat diketahui dari berbagai arah, diantaranya, hasil, informasi, ekonomis, pengawasan, efisiensi, pelayanan.

1. Analisa Kerja (Performance)

1. Proses penyewaan masih dilakukan dengan cara menulis di kwitansi sehingga masih terjadinya kesalahan pada saat penulisan penyewaan bus yang ingin disewa.

2. Sistem belum bisa memberikan informasi mengenai laporan transaksi bulanan secara realtime kepada Manager.

3. Membutuhkan waktu yang lama untuk melakukan pencarian data transaksi yang dicatat dalam buku besar.

2. Analisa Informasi (Information)

1. Keakuratan informasi yang disediakan kurang terjamin karena tidak ditampilkan secara realtime.

2. Pada saat ini informasi berupa data transaksi yang masih dicatat dalam buku besar sehingga keakuratan datanya kurang terjamin.

3. Masih lambatnya dalam pencarian data informasi yang digunakan untuk laporan kepada Manager.

3. Analisa Ekonomis (Economics)

1. Dalam jangka panjang biaya yang dibutuhkan akan cukup besar karena mengeluarkan biaya untuk membeli kertas dan alat tulis.

2. Proses pencatatan laporan masih menggunakan Buku Besar sehingga mengalami kesulitan apabila mencari data yang dibutuhkan.

4. Analisa Kontrol (Control)

1. Tidak adanya keamanan dalam penyimpanan data sehingga siapa saja dapat membuka dokumen.

2. Belum adanya pengontrolan sistem sehingga tidak dapat mendeteksi kesalahan yang terjadi pada prosesnya.

5. Analisa Efisiensi (Efficiency)

1. Masih membutuhkan waktu lama untuk pembuatan laporan transaksi.

2. Berdasarkan sistem yang berjalan saat ini kwitansi masih menggunakan kertas dan harus ditulis kembali sehingga tidak efisien.

6. Analisa Pelayanan (Service)

1. Membutuhkan waktu yang lama untuk melakukan pencarian riwayat transaksi.

\subsection{Metode Perancangan Sistem}

Untuk menganalisis prosedur yang berjalan penulis menggunakan alat dalam bentuk UML (Unified Modelling Language) melalui tahap: use case diagram,activity diagram, sequence diagram, dan class diagram. 
Bahasa pemrograman menggunakan PHP dengan berbasis Laravel Framework, basis data menggunakan MySQL, perangkat lunak pendukung menggunakan Visual Studio Code.

\subsection{Metode Pengembangan}

Metode pengembangan yang digunakan dalam penelitian ini yaitu metode Extreme Programming (XP). Dengan tahapan sebagai berikut:

1. Perencanaan

Aktivitas perencanaan dimulai dengan membentuk cerita pengguna. Anggota tim Extreme Programming (XP) kemudian menilai setiap cerita dan menentukan biaya yang diukur dalam development week. Tim Pelanggan dan Extreme Programming (XP) bekerja bersama untuk memutuskan bagaimana group story berikutnya (peningkatan perangkat lunak) kemudian dibangun oleh tim Extreme Programming (XP).

2. Desain

Extreme Programming (XP) menggunakan kartu CRC, untuk mengenali dan menetapkan kelas berorientasi objek yang bertepatan dengan peningkatan perangkat lunak.

3. Coding

Sebelum membuat kode, lebih baik membuat unit tes setiap cerita dimasukkan dalam peningkatan perangkat lunak. Extreme Programming (XP) menunjukkan bahwa dua orang bekerja sama di computerworkstation untuk membuat kode cerita (pair programming), untuk memberikan pemecahan masalah waktu nyata dan kualitas yang menjamin secara realtime. Setelah menyelesaikan pair programming, kode terintegrasi dengan pekerjaan lain (sintegrasi lanjutan).

4. $\quad$ Testing

Tes unit yang telah dibuat harus diimplementasikan menggunakan kerangka kerja dan penetapan dalam universal testing suite, integrasi dan validasi sistem dapat dilakukan setiap hari. Tes Penerimaan dilakukan oleh klien dan berfokus pada seluruh fitur dan sistem fungsional. Tes penerimaan diperoleh dari kisah-kisah pelanggan yang telah diimpor sebagai bagian dari versi perangkat lunak.

\subsection{Metode Pengujian Sistem}

Metode pengujian merupakan tahap akhir sebelum sistem yang telah dibuat diimplementasikan. Metode pengujian ini menggunakan black box testing, yaitu tes yang diperlukan untuk mencari fungsi perangkat lunak apakah sudah berfungsi sesuai kebutuhan, sehingga dapat memudahkan user untuk mengetahui letak kesalahannya.

Tabel 1. Black Box Testing

\begin{tabular}{|c|c|c|c|c|c|}
\hline NO & $\begin{array}{c}\text { Skenario } \\
\text { Pengujian }\end{array}$ & Test Case & $\begin{array}{l}\text { Hasil Yang } \\
\text { Diharapkan }\end{array}$ & Hasil Pengujian & $\begin{array}{c}\text { Kesimpul } \\
\text { an }\end{array}$ \\
\hline 1. & $\begin{array}{l}\text { Mengosong } \\
\text { kan kolom } \\
\text { pada form } \\
\text { login }\end{array}$ & - & $\begin{array}{l}\text { Sistem } \\
\text { menolak untuk } \\
\text { masuk menu } \\
\text { login dan } \\
\text { menampilkan }\end{array}$ & . & Valid \\
\hline
\end{tabular}




\begin{tabular}{|l|l|l|l|l|}
\hline 2. & $\begin{array}{l}\text { Pengujian } \\
\text { login } \\
\text { apabila } \\
\text { email dan } \\
\text { password } \\
\text { salah }\end{array}$ & $\begin{array}{l}\text { sistem } \\
\text { menolak untuk } \\
\text { masuk menu } \\
\text { login dan } \\
\text { menampilkan } \\
\text { pesan } \\
\text { error(These } \\
\text { credentials do } \\
\text { not match our } \\
\text { records.) }\end{array}$ \\
\hline
\end{tabular}

\section{HASIL DAN PEMBAHASAN}

\subsection{Usecase Diagram Sistem Usulan}

Pada use case diagram ini, Admin mengelola semua aksi, Marketing dapat mengelola semuanya kecuali data master dan Log aktivitas, Marketing tidak dapat menambah dan mengedit data master, Manager hanya dapat melihat dashboard, laporan transaksi, operasional dan $\log$ aktivitas.

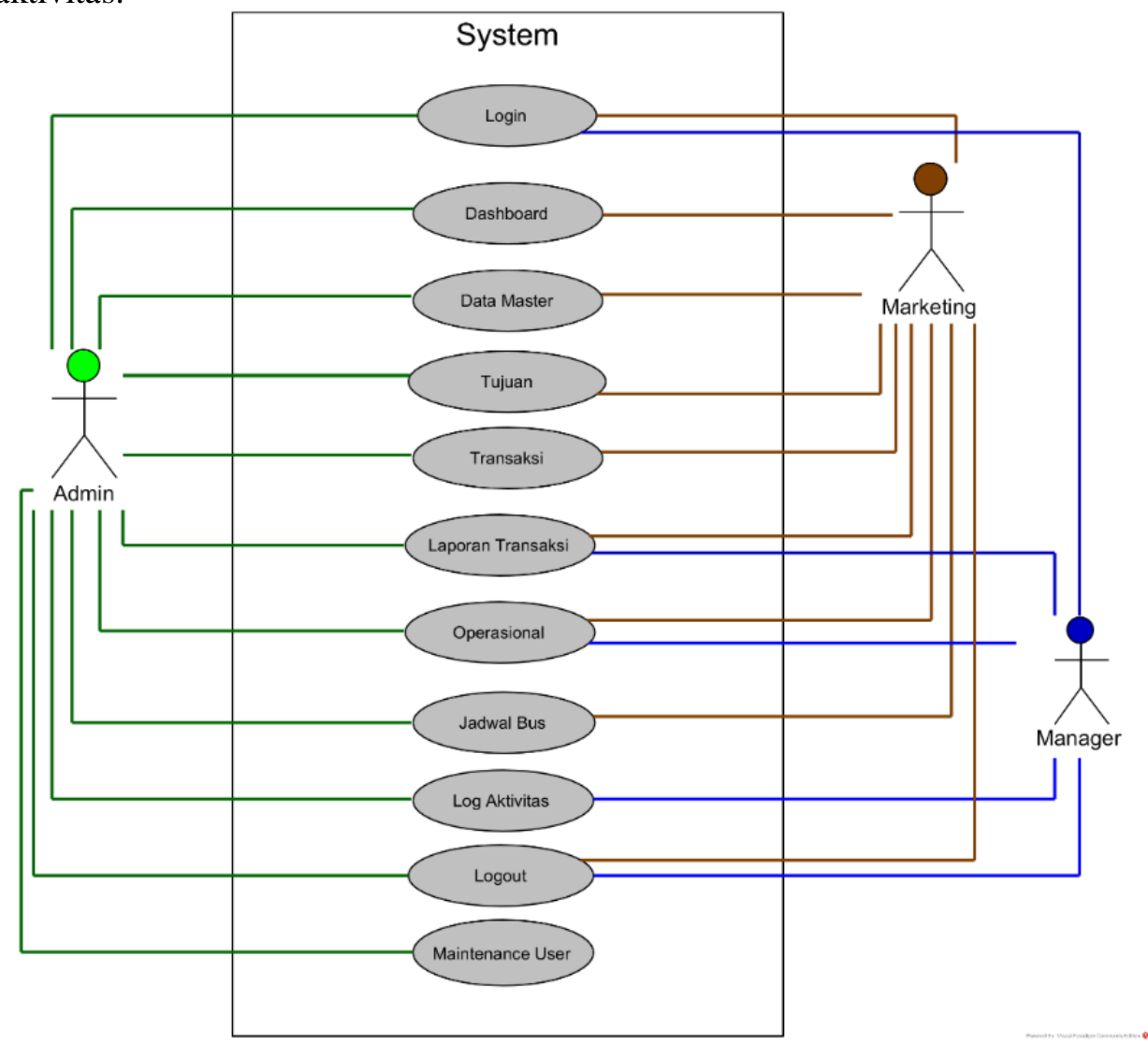

Gambar 1. Use Case Diagram Usulan

\subsection{Activity Diagram Sistem Usulan}

Dimulai dari marketing membuka halaman website kemudian sistem menampilkan halaman dashboard dan marketing mengklik menu Transaksi dan sistem menampilkan menu Transaksi kemudian marketing mengelola menu transaksi kemudian invoice bisa di cetak atau di 
kirim, kemudian marketing mengklik menu Operasional dan sistem menampilkan menu Operasional kemudian marketing mengelola menu Operasional, kemudian marketing mengklik menu Laporan Transaksi dan sistem menampilkan menu Laporan Transaksi kemudian marketing mengelola menu Laporan Transaksi, kemudian manager menerima Laporan Transaksi dari marketing.

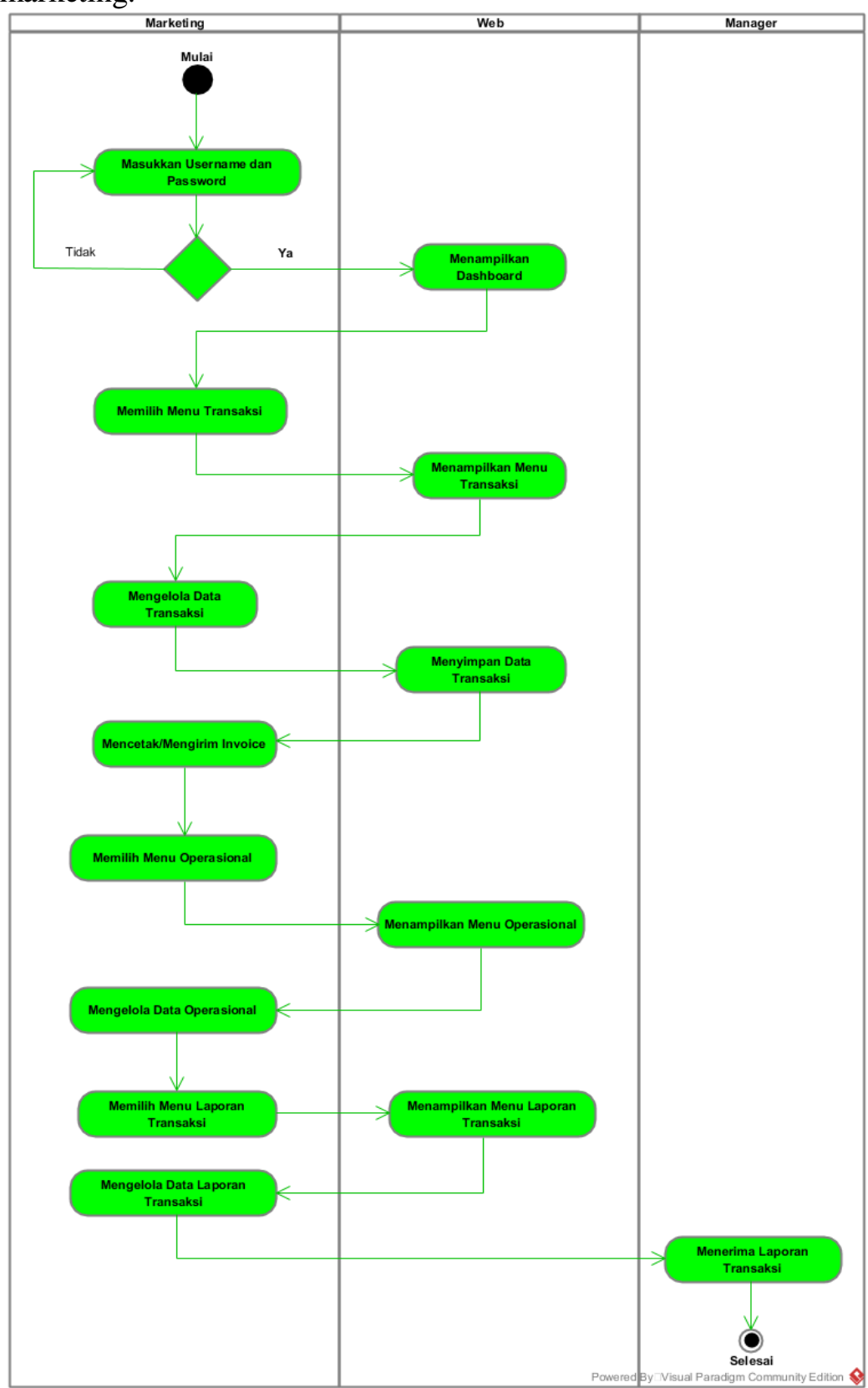

Gambar 2. Activity Diagram Penyewaan Usulan

\subsection{Sequence Diagram Sistem Usulan}

Bedasarkan Gambar 3. Sequence Diagram terdapat:

1. Terdapat 3 Aktor yang melakukan aktivitas.

2. Terdapat 1 Had Lifelineyaitu: Login

3. Terdapat 8 Entity Lifeline yaitu: Dashboard, Data Master, Tujuan, Transaksi, Laporan Transaksi, Operasional, Jadwal Bus, Log Aktivitas 


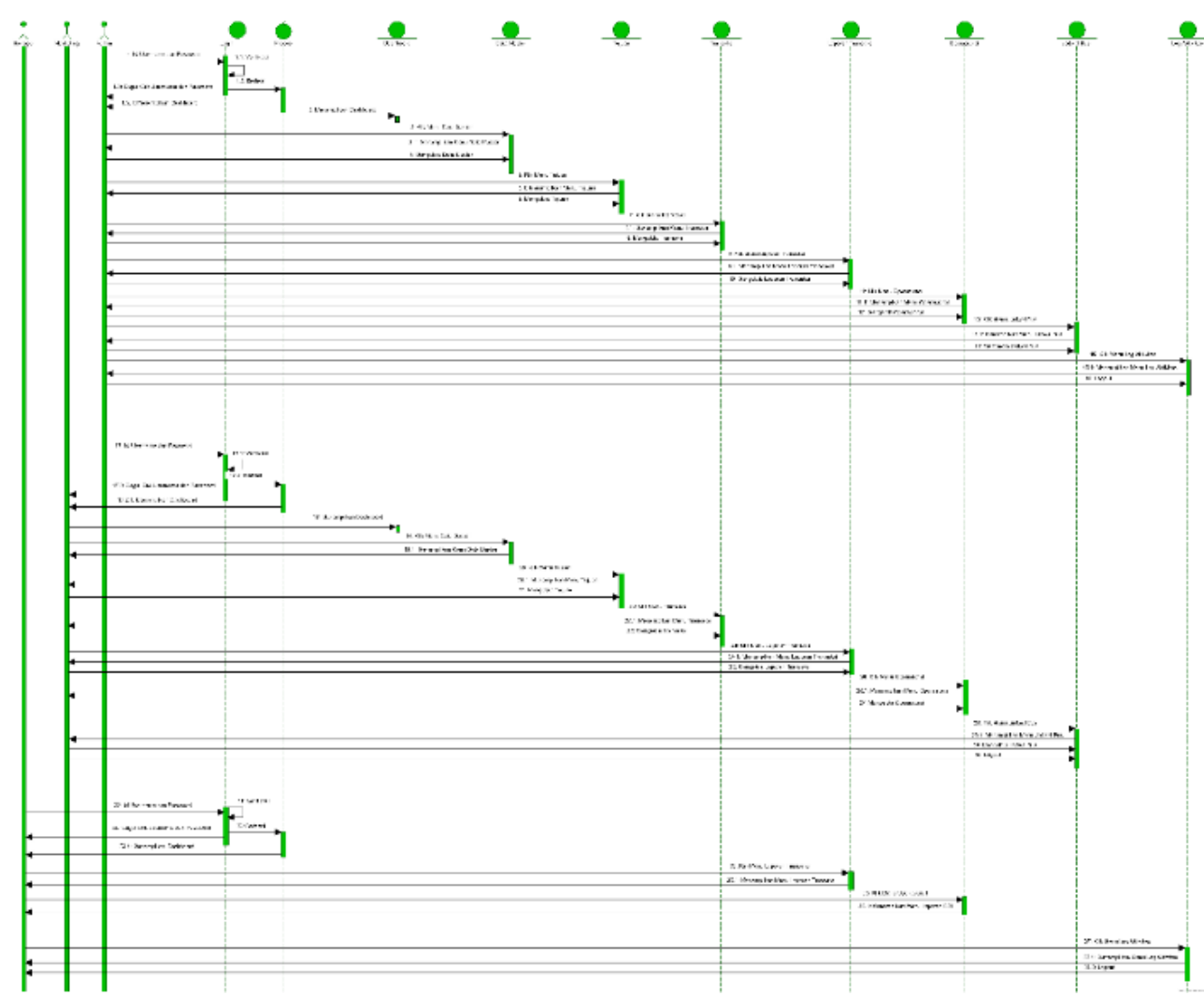

Gambar 3. Sequence Diagram Usulan

\subsection{Class Diagram Usulan}

Pada class diagram terdapat beberapa tabel diagram diantaranya tabel sopir, user, helper bus, tujuan, transaksi, laporan transaksi, surat perintah jalan, laporan surat perintah jalan dan log aktivitas.
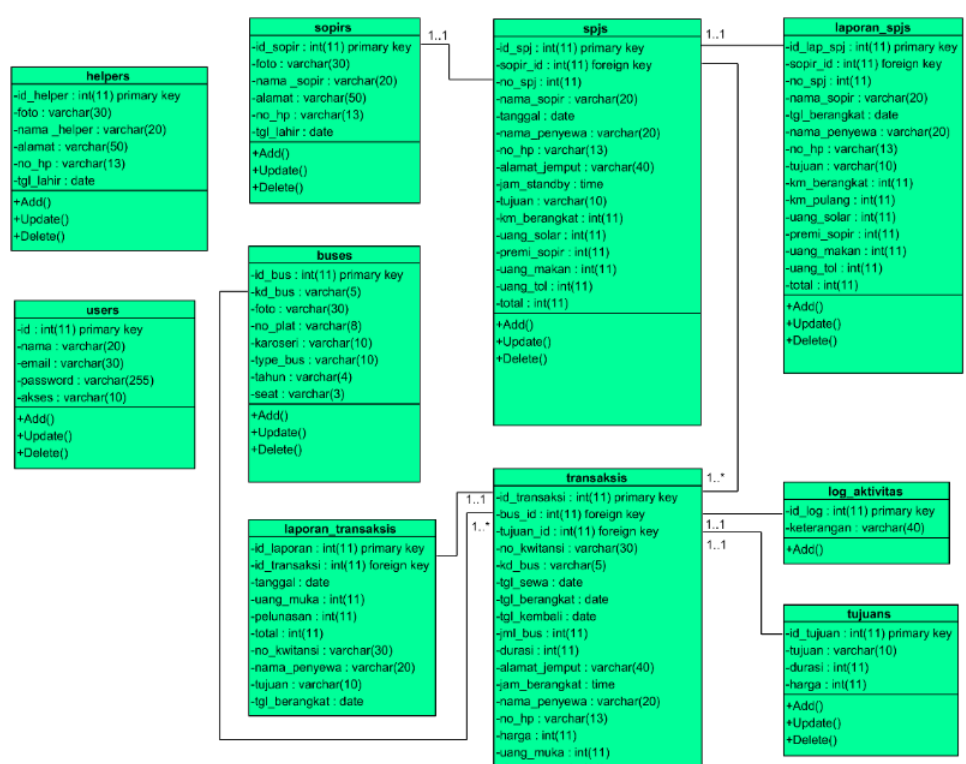

Gambar 4. Class Diagram Usulan 


\subsection{Program}

\subsubsection{Login}

Ini adalah tampilan login dimana user harus menginput email dan password yang valid dan sudah pernah terdaftar sebelumnya.

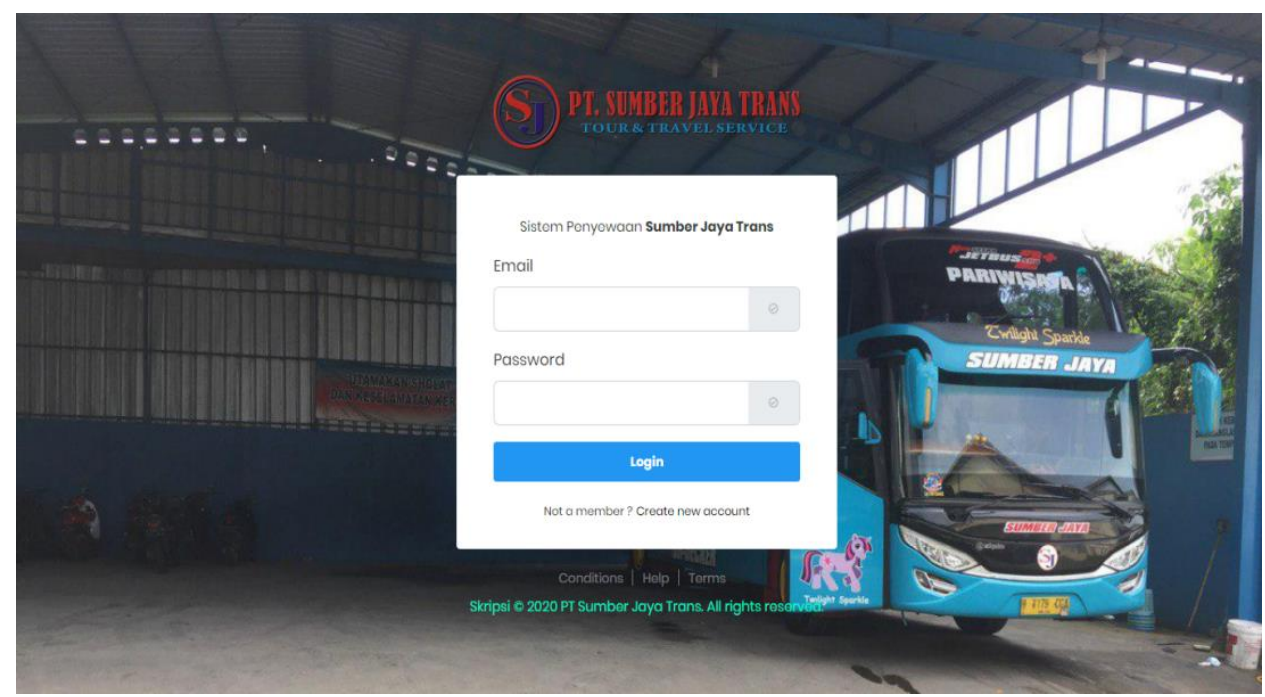

Gambar 5. Tampilan Login

\subsubsection{Dashboard}

Pada tampilan ini menunjukkan halaman utama dari program.
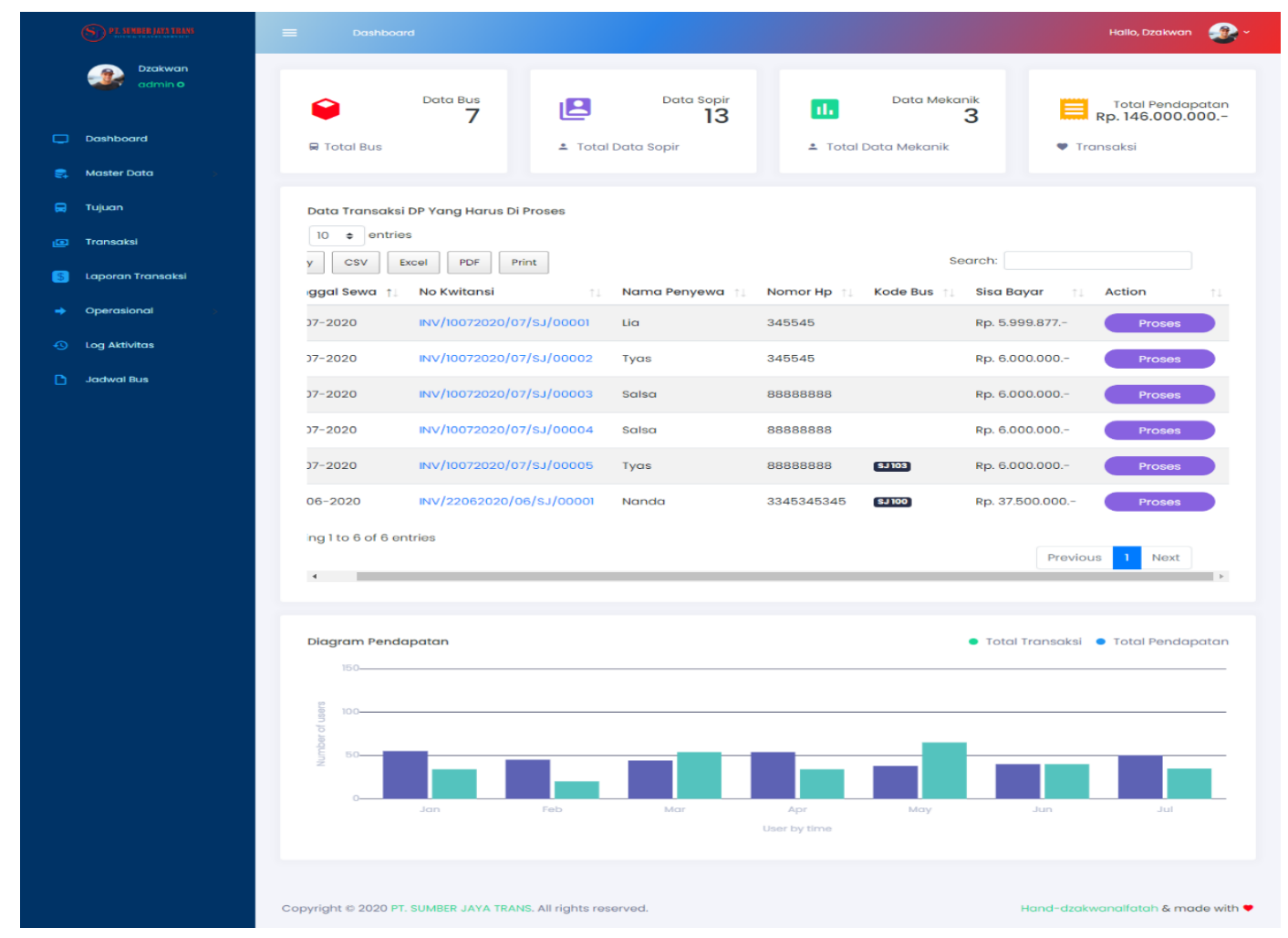

Gambar 6. Tampilan Dashboard 


\subsubsection{Transaksi}

Pada halaman ini menampilkan detail data transaksi secara keseluruhan.
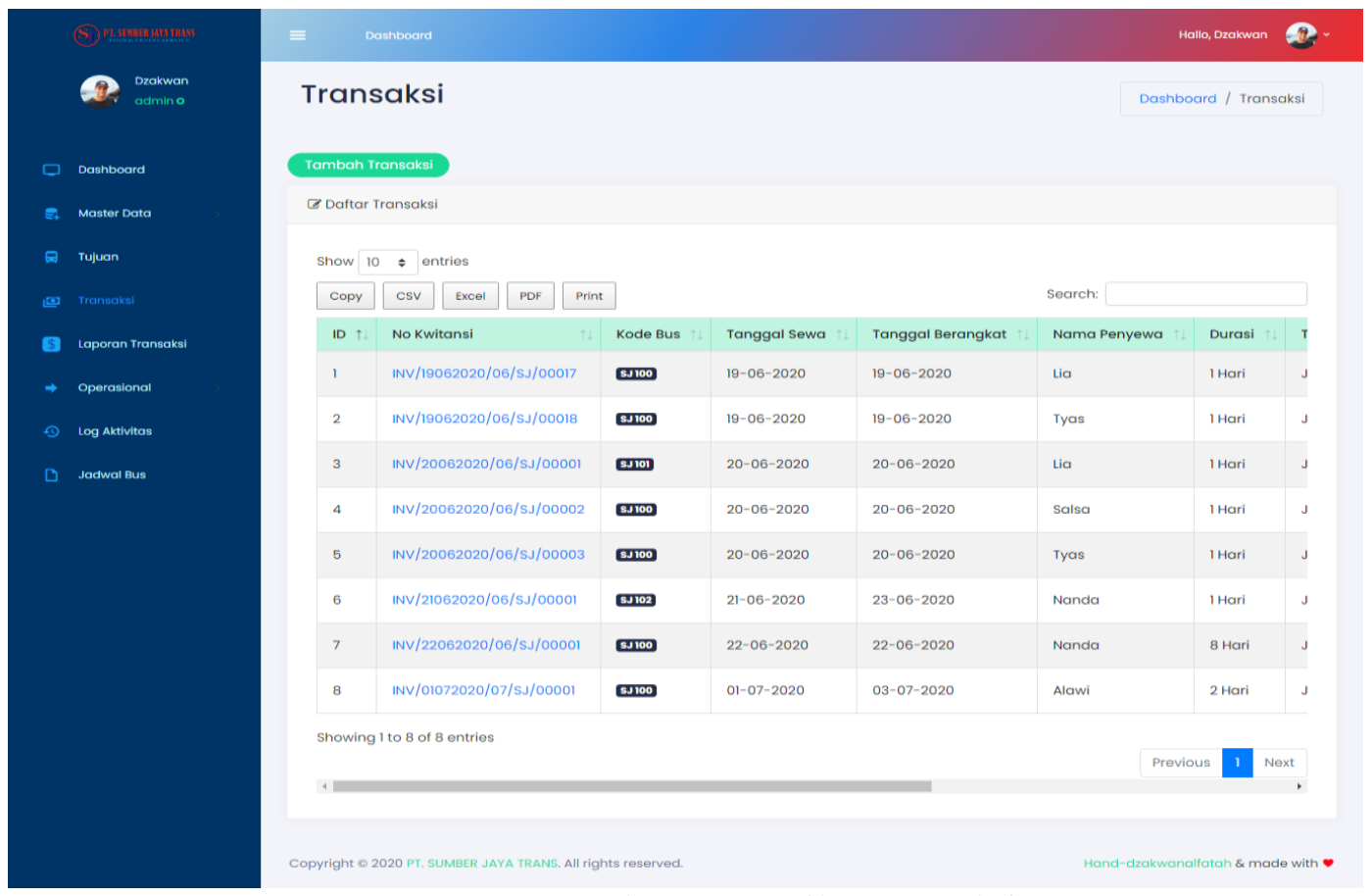

Gambar 7. Tampilan Transaksi

\subsubsection{Laporan Transaksi}

Pada halaman ini menampilkan laporan transaksi secara menyuluruh.
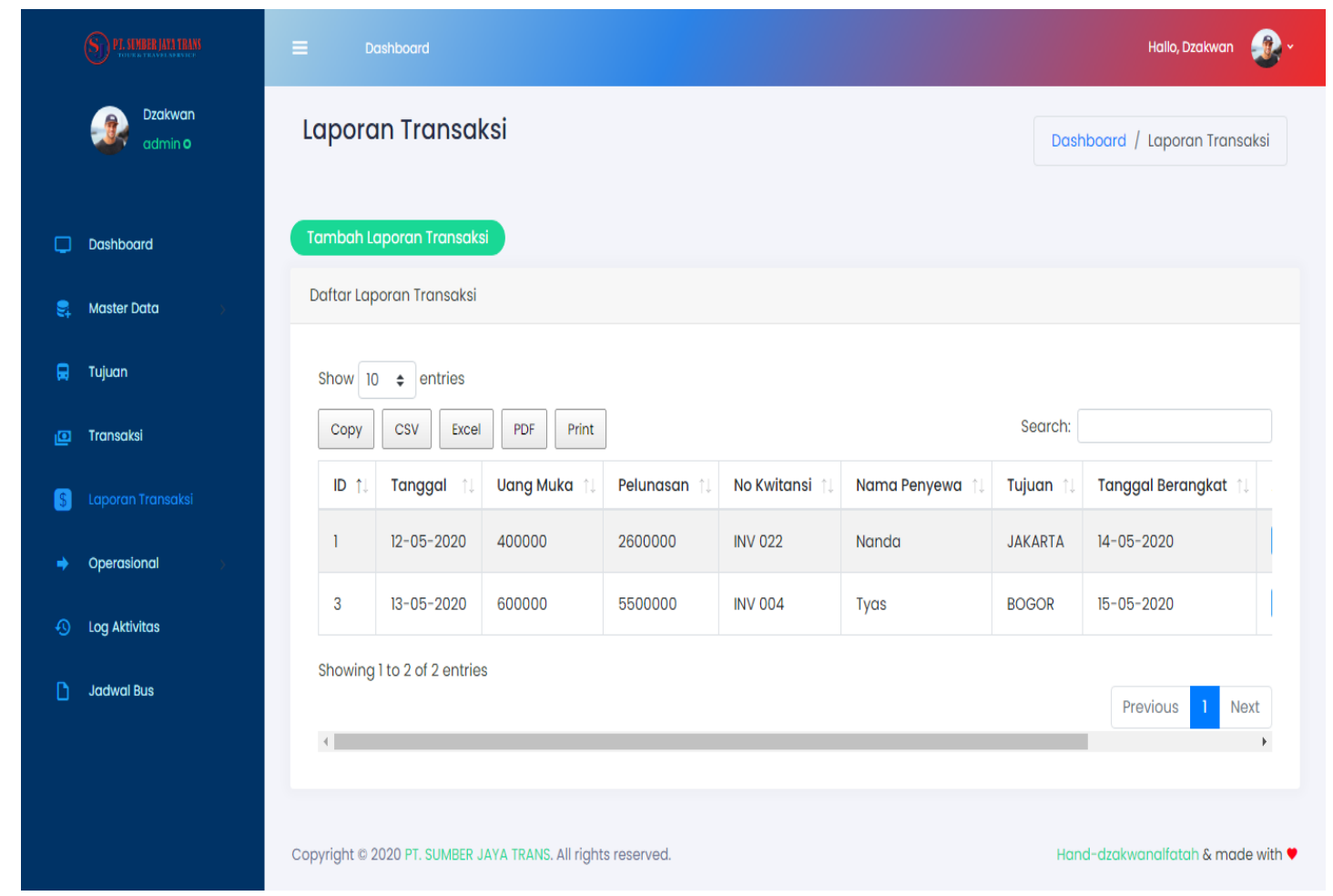

Gambar 8. Tampilan Laporan Transaksi 


\subsubsection{Surat Perintah Jalan}

Pada gambar 9. menampilkan halaman data surat perintah jalan yang berisi kode bus, nama sopir, tanggal, nama penyewa, no hp, alamat jemput dan jamnya.
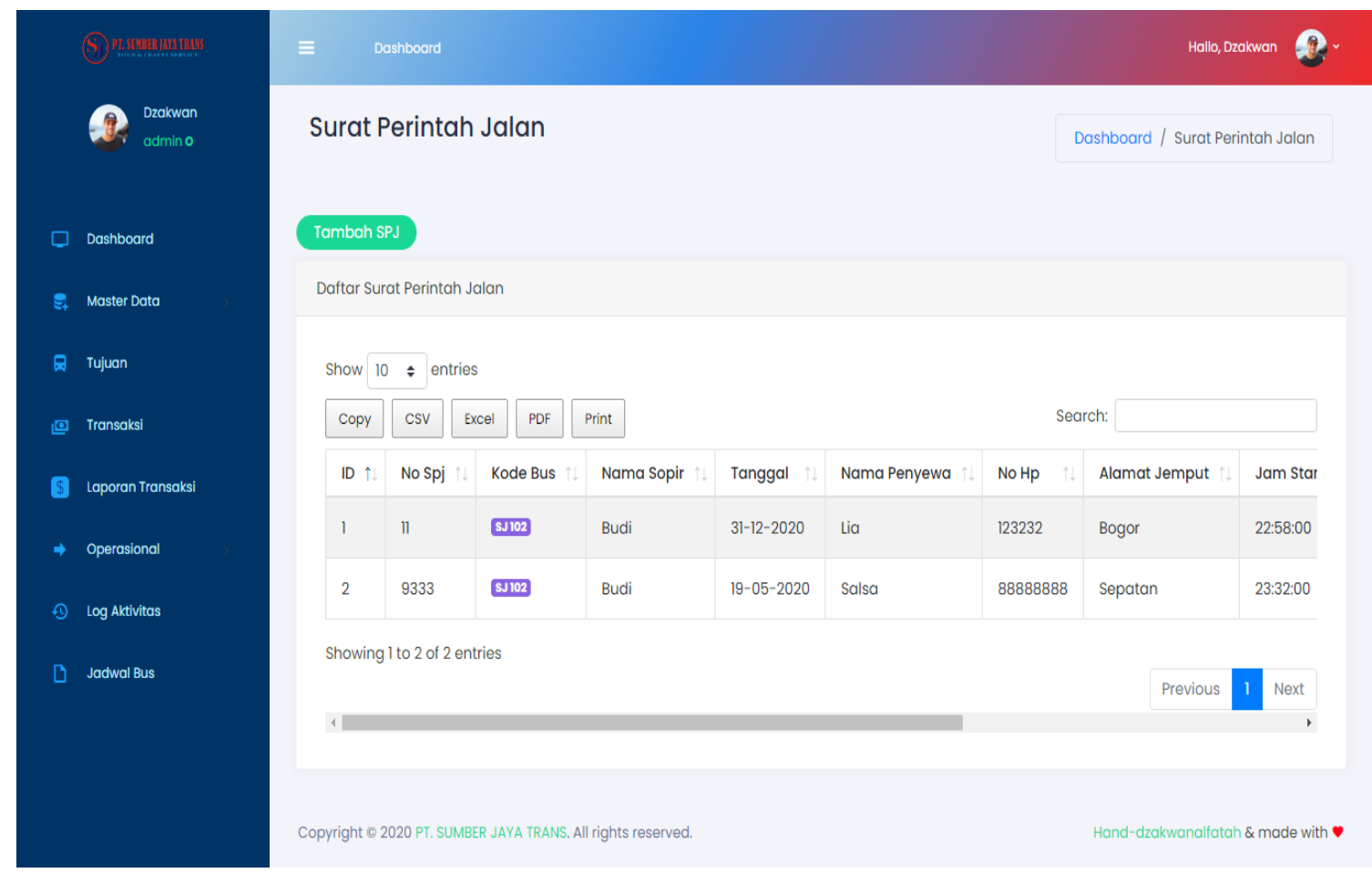

Gambar 9. Tampilan Surat Perintah Jalan

\subsubsection{Laporan Surat Perintah Jalan}

Pada gambar 10. menampilkan halaman laporan spj yaitu laporan surat perintah jalan secara keseluruhan.

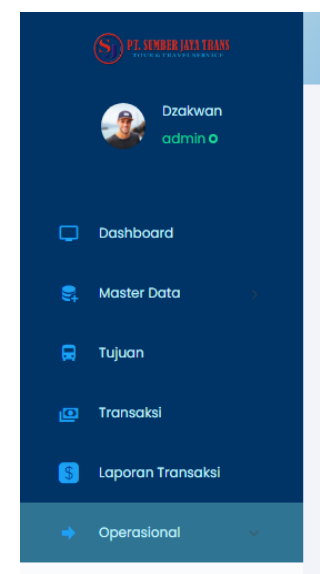

Surat Perintah Jalan

Laporan SPJ

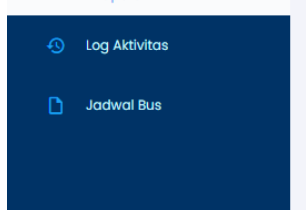

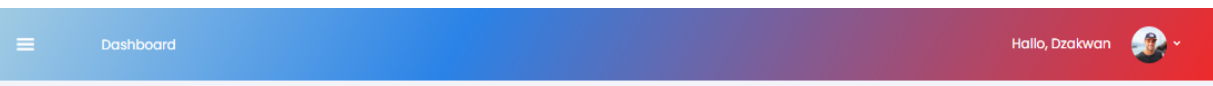

\begin{tabular}{l|l} 
Laporan Spj & Dashboard / Laporan Spj
\end{tabular}

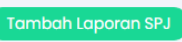

6 Daftar Laporan Surat Perintah Jalan

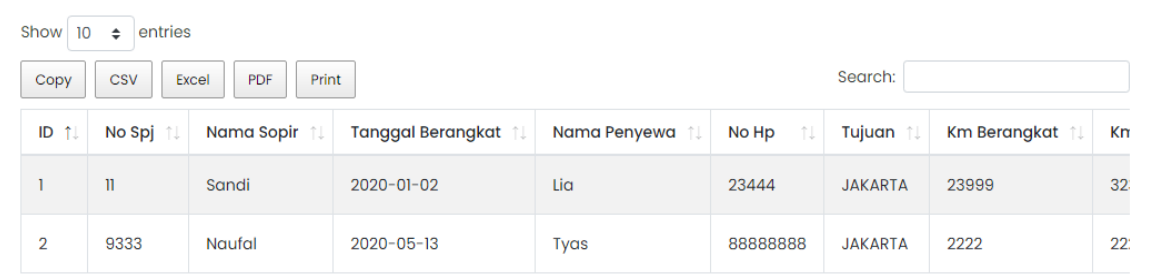

Showing 1 to 2 of 2 entries

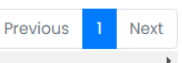

Hand-dzakwanalfatah \& made with $\bullet$

Gambar 10. Tampilan Laporan Surat Perintah Jalan 


\subsubsection{Log Aktivitas}

Gambar ini menampilkan halaman log aktivitas secara menyeluruh yang berkaitan dengan kegiatan yang dilakukan user terhadap data-data yang terdapat dalam sistem.
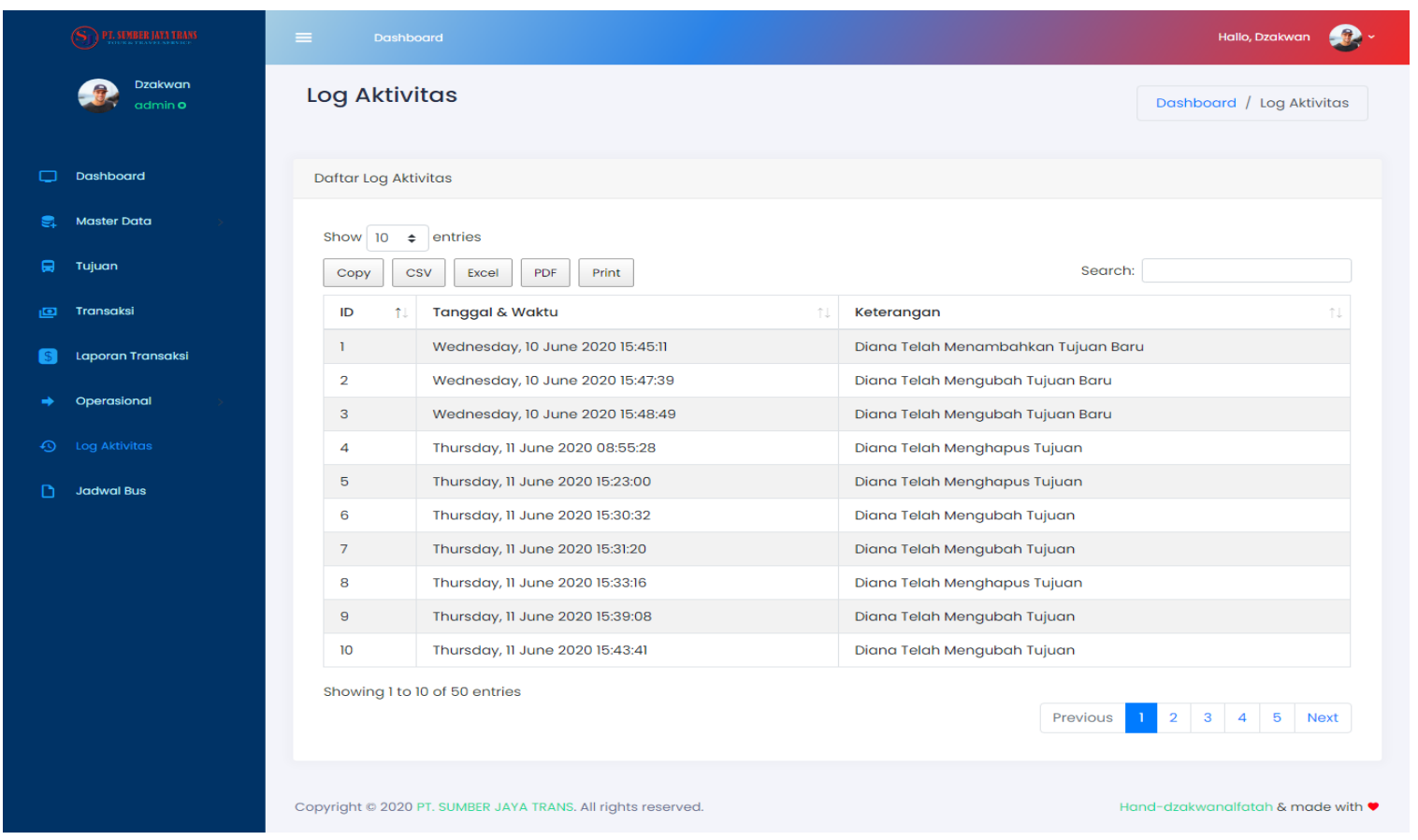

Gambar 11. Tampilan Log Aktivitas

\subsubsection{Jadwal Bus}

Pada gambar 12. menampilkan halaman aktivitas jadwal bus berdasarkan tanggalnya.
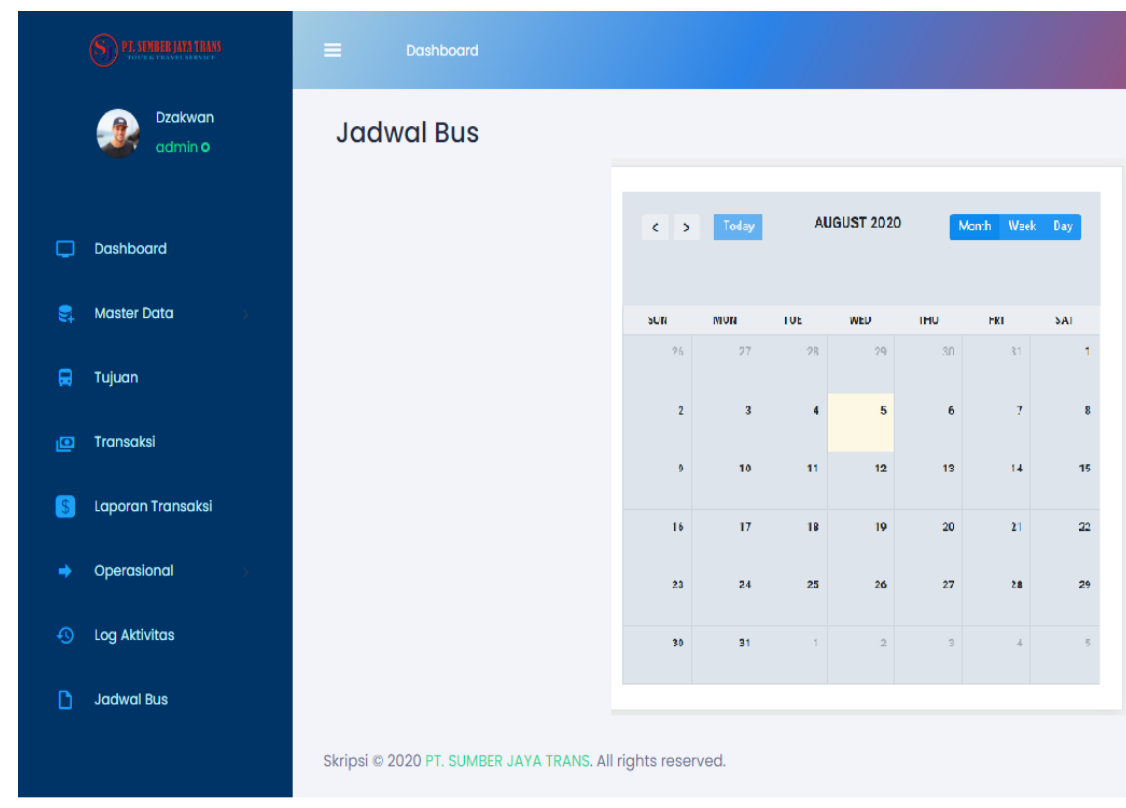

Hallo, Dzakwan 9 .

Gambar 12. Tampilan Jadwal Bus 


\section{KESIMPULAN}

Pada proses bisnis penyewaan bus yang sedang berjalan saat ini di PT Sumber Jaya Trans Tangerang dalam pelaksanaan semua kegiatan proses bisnis masih dilakukan secara manual, sehingga dibuat sistem penyewaan bus dilakukan dengan menggunakan metode PIECES.

Pada proses transaksi ditunjang dengan adanya sistem penyewaan bus yang dapat dilakukan dengan lebih baik, mudah dan cepat, sehingga meminimalkan kehilangan data transaksi yang disebabkan oleh kerusakan atau hilangnya dokumenpenyewaan, menu search untuk mempermudah proses pencarian data agar tidak memakan waktu yang lama,serta menu jadwal bus untuk memudahkan marketing melihat bus yang sedang disewa atau akan disewa.

Dengan adanya sistem penyewaan bus pada PT Sumber Jaya Trans Tangerang, memudahkan Manager mengontrol semua kegiatan penyewaan bus pada PT Sumber Jaya Trans Tangerang.

\section{SARAN}

Perlu adanya pihak yang bertanggung jawab terhadap sistem ini yaitu admin sebagai operator sistem. Perlu dilakukan pengarahan dan pelatihan kepada admin, marketing dan manager agar penggunaan sistem lebih optimal. Pihak yang diberi tanggung jawab harus jujur dan transparansi kepada manager.

\section{DAFTAR PUSTAKA}

[1] Selmi, S., dan Rofiah, S., 2018, Sistem Informasi Pemesanan Tiket Bus Pariwisata Berbasis Web, Bina Insani Ict Journal, Vol.5 No. 1.

[2] Rachman, K., 2018, Sistem Informasi Penyewaan Bus Pariwisata Berbasis Web Di DMH Trans, Doctoral dissertation, Universitas Komputer Indonesia.

[3] Ginanjar, P. A., dan Tanone, R., 2017, Aplikasi Pemesanan Bus Pariwisata Menggunakan Payment Gateway Berbasis Android, Studi kasus: Blue Star, Salatiga, Prosiding, Vol.7 No. 1.

[4] Zakaria, H., dan Muhammad, A., 2019, Rancang Bangun Sistem Informasi Reservasi Pemesanan Bus Pariwisata Berbasis Web Pada Cv. Abiyyu Trans, In Prosiding Seminar Informatika Dan Sistem Informasi, Vol. 3 No. 3.

[5] Wahyuno, T., 2016, Pembangunan Sistem Informasi Pemesanan Tiket Bus Berbasis Website Pada Po. Handoyo, Skripsi, Universitas Sebelas Maret Jogjakarta.

[6] Mulyadi, 2016, Sistem Akuntansi, Jakarta: Salemba Empat.

[7] Hidayat, W., Mahmuriyah, R., dan Safitri, S. N. R., 2016, Media Visual Berbentuk Katalog Produk Sebagai Media Promosi, Journal Sensi, Vol.2 No. 2.

[8] Widodo, B. P., dan Purnomo, H. D., 2016, Perancangan Aplikasi Pencarian Layanan Kesehatan Berbasis HTML 5 Geolocation, Jurnal Sistem Komputer.

[9] Darmawan, 2016, Dasar Penyewaan, Yogyakarta: Andi. 
ISSN: 2356-5209

[10] Huda, N., 2019, Analisis Kinerja Website PT PLN (PERSERO) Menggunakan Metode PIECES, Jurnal SISTEMASI, Vol. 8 No.1. 